\title{
APPLICATION OF VOLTAMMETRY IN BIOMEDICINE - RECENT ACHIEVEMENTS IN ENZYMATIC VOLTAMMETRY
}

\author{
Rubin Gulaboski ${ }^{1}$, Valentin Mirceski ${ }^{2,3}$ \\ ${ }^{1}$ Faculty of Medical Sciences, Goce Delčev University, Štip, Republic of Macedonia \\ ${ }^{2}$ Faculty of Natural Sciences and Mathematics, Ss. Cyril and Methodius University, \\ Skopje, Republic of Macedonia \\ ${ }^{3}$ Department of Inorganic and Analytical Chemistry, University of Lodz, \\ Tamka 12, 91-403 Lodź, Poland \\ rubin.gulaboski@ugd.edu.mk; valentin@pmf.ukim.mk
}

\begin{abstract}
Protein-film voltammetry (PFV) is considered the simplest methodology to study the electrochemistry of lipophilic redox enzymes in an aqueous environment. By anchoring particular redox enzymes on the working electrode surface, it is possible to get an insight into the mechanism of enzyme action. The PFV methodology enables access to the relevant thermodynamic and kinetic parameters of the enzymeelectrode reaction and enzyme-substrate interactions, which is important to better understand many metabolic pathways in living systems and to delineate the physiological role of enzymes. PFV additionally provides important information which is useful for designing specific biosensors, simple medical devices and bio-fuel cells. In the current review, we focus on some recent achievements of PFV, while presenting some novel protocols that contribute to a better communication between redox enzymes and the working electrode. Insights to several new theoretical models that provide a simple strategy for studying electrode reactions of immobilized enzymes and that enable both kinetic and thermodynamic characterization of enzyme-substrate interactions are also provided. In addition, we give a short overview to several novel voltammetric techniques, derived from the perspective of square-wave voltammetry, which seem to be promising tools for application in PFV.
\end{abstract}

Keywords: protein-film voltammetry; surface electrode mechanisms; enzyme-substrate interactions; modified electrodes; kinetics of electron transfer

\section{АПЛИКАЦИЈА НА ВОЛТАМЕТРИЈАТА ВО БИОМЕДИЦИНАТА - СКОРЕШНИ ПОСТИГНУВАЊА ВО ВОЛТАМЕТРИЈАТА НА ЕНЗИМИ}

Волтаметрија со протеински филм (PFV) е наједноставна методологија за студирање на електрохемиските својства на т.н. липофилни редокс-ензими во водна средина. Со апсорпција на даден редокс-ензим на површината од работна електрода е возможно да се студира механизмот и својствата на тој ензим. Покрај тоа, методологијата на PFV овозможува и определување на важни кинетички и термодинамички параметри на интеракциите ензим-електрода и ензим-супстрат, што е особено важно за подобро разбирање на физиолошките функции на ензимите и на голем број метаболички патишта кај живите организми. Со техниката PFV се добиваат важни информации за дизајнирање на биосензори, едноставни медицински инструментални уреди и горивни био-ќелии. Во рамките на овој ревијален труд, е направен преглед на некои скорешни постигнувања на PFV, при што се презентирани нови експериментални протоколи што придонесуваат за подобра комуникација помеѓу редокс ензимите и работната електрода. Притоа посебно внимание е посветено на неколку нови теоретски волтаметриски модели кои помагаат во развој на стратегија за студирање на електродните реакции на апсорбираните ензими и кои овозможуваат разработка на методи за кинетички и термодинамички определувања кај овие системи. Покрај тоа, во трудот е 
даден и краток преглед на неколку нови волтаметриски техники изведени од квадратно-брановата волтаметрија, кои можат да станат значајни алатки во апликацијата на PFV.

Клучни зборови: волтаметрија со протеински филм; површински електродни механизми; ензимско-супстратни интеракции; модифицирани електроди; кинетика на електронски трансфер

\section{INTRODUCTION}

Electrochemistry is a branch of physical chemistry that mainly considers the process of charge (electrons and/or ions) transfer between two conjoined systems, which are frequently linked to corrosion, metal protection and various types of energy storage systems (batteries). Indeed, these are the most known fields in which electrochemistry plays a major role. However, in the last 30 years we have seen significant progress of electrochemistry in many areas of biomedical sciences [1-3]. Electrochemical techniques most frequently encountered in biomedical investigations are potentiometry [4] and voltammetry [4-5]. Voltammetric techniques are recognized as cheap, simple and powerful tools provided by commercial electrochemical instrumentation. The driving force in voltammetry is the energy of electrons (controlled via the applied electrode potential difference), while the relevant measuring physical parameter is the intensity of the Faradaic current. The Faradaic current occurs due to an electron exchange between the working electrode and electroactive species, either present in the solution or being immobilized on the electrode surface, which undergo redox transformation at the electrode/electrolyte interface.

Voltammetry is used in many laboratories dealing with chemical, biochemical, environmental and physical analyses. It is a versatile technique for the investigation of mechanisms, kinetics and thermodynamics of metal-ligand complexation reactions [6], drug action [7-8] and drug-DNA interactions [9-10]. It is particularly important for the detection and quantification of biochemical and physiological active compounds [3, 8], and is a technique which underlies the operation of many biochemical sensors [11-14]. In addition, important studies related to the application of voltammetry for studying enzyme biochemistry [15] and biophotoelectrochemistry have been already conducted [16].

In the present review, we focus on the application of voltammetry for studying lipophilic redox enzymes and redox active proteins via immobilization on the electrode surface, an approach known as protein-film voltammetry (PFV). While address- ing relevant experimental studies published in the last several years, we also review several theoretical models which are relevant for the advanced application of pulse voltammetric techniques in PFV. Finally, a few novel voltammetric techniques will be briefly reviewed as promising tools for further advanced applications in PFV.

\section{RESULTS AND DISCUSSION}

\subsection{Probing electrochemical features of immobilized redox enzymes and proteins}

Since the introduction of PFV, which is considered as the simplest experimental methodology for studying electrochemistry of redox enzymes [17-18], there has been fast progress in the field of enzymatic voltammetry [15-20]. Redox enzymes belong to the class of oxidoreductases and represent more than $30 \%$ of all known proteins which are involved in numerous biological processes comprising electron transfers (e.g., respiration and molecular signalling). Many essential biochemical reactions in living organisms are thermodynamically possible due to their coupling to the hydrolysis of ATP, supported by the action of numerous enzymes. Due to specific catalytic features of the enzymes, the methodology of PFV is acknowledged as a useful approach in designing selective sensors for various substrates $[15,17,19,20]$.

In the context of an electrochemical experiment, it is possible to study electrochemical and chemical features of particular lipophilic enzymes by anchoring the enzyme onto the surface of the working electrode in a form of a monolayer (via self-assembling adsorption or by covalent bonding). The methodology is not limited to the redox enzymes only; in addition, it can be accordingly applied to redox active proteins and various coenzymes (Fig. 1). Commonly, two general experimental approaches can be taken if direct electron transfer takes place between the adsorbed enzyme and the working electrode: (i) voltammetric characterization due to the electrochemical activity of the redox enzyme, conducted in the absence of a substrate (Fig. 2A); and (ii) voltammetry based on the enzymatic catalytic reaction in the presence of the enzyme substrate (the so-called regenerative 
surface EC' mechanism) (Fig. 2B). In both scenarios, thermodynamic and kinetic parameters of the enzyme-electrode reaction can be obtained, togeth- er with the kinetic characterization of the enzymesubstrate reaction $[3-6,10,15-21]$.



Fig. 1. Schematic representation of protein-film voltammetric set-up, with the Au-working electrode modified with Au-stabilized nanoparticles
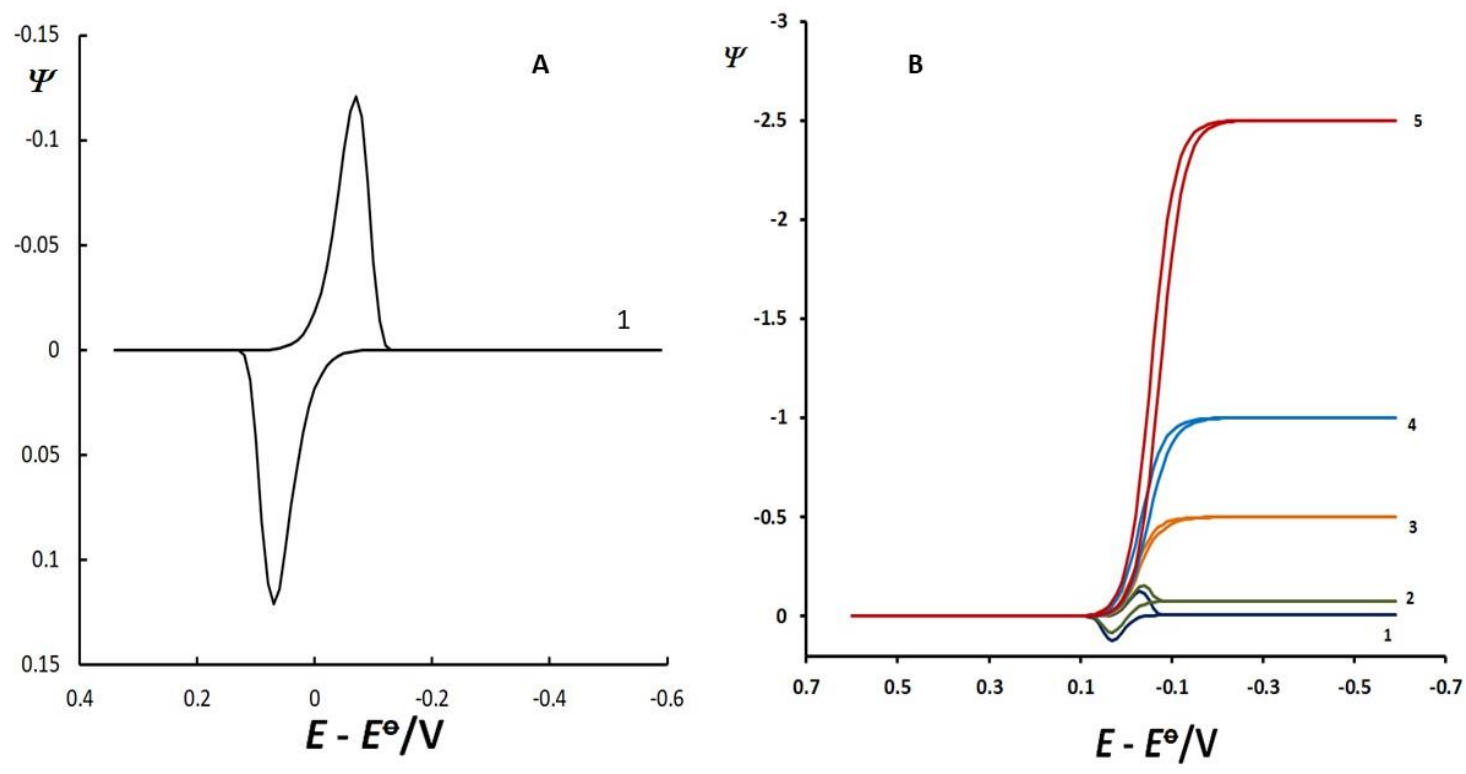

Fig. 2. Theoretical cyclic staircase voltammogram of a lipophilic redox enzyme recorded in the absence of a substrate (A). Cyclovoltammetric patterns in (B) represent the effect of increasing substrate concentration simulated for a regenerative surface EC' (electrochemical-catalytic) electrode mechanism of type $\mathrm{A}(\mathrm{ads})+n \mathrm{e}^{-} \leftrightarrow \mathrm{B}(\mathrm{ads})+\mathrm{S} \rightarrow \mathrm{A}(\mathrm{ads})$. The dimensionless kinetic parameter of electron transfer was set to $K=0.025$ in all cases. The concentration of the substrate " $\mathrm{S}$ " in voltammograms (B) was set to 0 mol/l

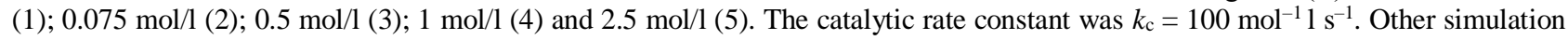
parameters were: time duration of potential steps $t=0.01 \mathrm{~s}$; potential step $\mathrm{d} E=0.01 \mathrm{~V}$, number of electrons $n=1$, electron transfer coefficient $\alpha=0.5$, and temperature $T=298 \mathrm{~K}$. 
Several comprehensive reviews have been dedicated to the experimental achievements of PFV in recent years [8, 15, 19-21]. In addition, valuable theoretical models have been developed under voltammetric conditions [22-40] that provide a means for qualitative characterization of reaction mechanisms. In $[6,15-17,20-40]$, important theoretical methodologies to estimate kinetics and thermodynamics of redox enzymes have been presented. However, it must be noted that the main challenge in experimental aspects of PFV is to establish an efficient electronic communication between the electrode and the enzyme, whose bulky structural segments (electrochemically inac- tive polypeptide backbones) frequently hinder efficient electron exchange [19, 41]. This is because many enzymes contain active sites that are deeply buried in their quaternary structure [15-19], while their polypeptide backbones are commonly attached to the electrode surface and act as electrical insulators. So far, cytochromes, heme-based enzymes, peroxidases, hydrogenases, some quinoproteins and enzymes containing cations of transient metals such as $\mathrm{Mo}, \mathrm{Co}, \mathrm{Cu}$ and $\mathrm{W}$, have been most frequently studied with PFV [19]. Bilirubin oxidase and glucose oxidase are rare examples of enzymes undergoing efficient, direct electron transfer with a few unmodified working electrodes [15-19].

T a ble 1

An overview of recent studies of redox enzymes conducted at modified electrode surfaces with voltammetric techniques

\begin{tabular}{|c|c|c|c|c|}
\hline Enzyme analyzed & $\begin{array}{l}\text { Working } \\
\text { electrode }\end{array}$ & Surface modified with & Substrate & Ref. \\
\hline Cellobiose dehydrogenase & $\mathrm{Au}$ & Cysteine & Quinones & {$[60]$} \\
\hline Cellobiose dehydrogenase & $\begin{array}{l}\text { Graphite } \\
\text { electrode }\end{array}$ & $\mathrm{Pt} / \mathrm{Pd}$ nanoparticles + nanotubes & Lactose & {$[61]$} \\
\hline Cellobiose dehydrogenase & $\mathrm{Au}$ & $\begin{array}{l}\text { Positively charged polyethyleneimine } \\
\text { gold nanoparticles }\end{array}$ & Lactose & {$[62]$} \\
\hline Cellobiose dehydrogenase & Glassy carbon & Au-nanoparticles & Glucose & [58] \\
\hline Cellobiose dehydrogenase & $\mathrm{Au}$ & Cysteine + maleimide & l & [63] \\
\hline Bilirubin oxidase & $\mathrm{Au}$ & Maleimide/thiol & Oxygen & [64] \\
\hline Bilirubin oxidase & Glassy carbon & Cabon nanofibers in presence of $\mathrm{NaCl}$ & Oxygen & {$[65]$} \\
\hline Glucose oxidase & Glassy carbon & Phenazine ethosulfate & Glucose & [66] \\
\hline Lactate oxidase & $\mathrm{Au}$ & $\begin{array}{l}\text { Multiwalled carbon nanotubes + meth- } \\
\text { ylene blue }\end{array}$ & Lactate & {$[67]$} \\
\hline FAD-glucose dehydrogenase & $\mathrm{Au}$ & $\begin{array}{l}\text { Multiwalled carbon nanotubes + meth- } \\
\text { ylene blue }\end{array}$ & Glucose & {$[67]$} \\
\hline Glucose dehydrogenase & Glassy carbon & $\begin{array}{l}\text { Pyrroloquinoline quinone + poly }(4- \\
\text { vinylpyridine }) \text { plymer with Os }\end{array}$ & Glucose & {$[68]$} \\
\hline Glucose dehydrogenase & Glassy carbon & Enzyme fused with cytochrome C & Glucose & [69] \\
\hline Glucose oxidase & Glassy carbon & 3-aminopropyltriethoxysilane & Glucose & {$[70]$} \\
\hline Glucose oxidase & $\begin{array}{l}\text { Boron doped dia- } \\
\text { mond }\end{array}$ & $\begin{array}{l}\text { functionalized } \\
\text { with 3-aminopropyltriethoxysilane }\end{array}$ & Glucose & [71] \\
\hline Pyranose dehydrogenase & $\begin{array}{l}\text { Graphite } \\
\text { electrode }\end{array}$ & $\begin{array}{l}\text { Osmium redox polymer with poly- } \\
\text { (ethylene glycol)(400) diglycidyl ether }\end{array}$ & Glucose & {$[72]$} \\
\hline Horseradish peroxidase & $\begin{array}{l}\text { Carbon paste } \\
\text { electrode }\end{array}$ & Silica sol-gel & 2-aminophenol & {$[73]$} \\
\hline Glucose oxidase & Carbon fibers & Graphene oxide & Glucose & [74] \\
\hline Flavohemoglobin & Graphite & Os-polymer & Oxygen & [75] \\
\hline Fructose dehydrogenase & $\begin{array}{l}\text { Carbon } \\
\text { (with cryogel) }\end{array}$ & Bilirubin & Fructose & {$[76]$} \\
\hline $\begin{array}{l}\text { D-Fructose dehydrogenase ( } \Delta 1 c \text { FDH } \\
\text { variant with lack of } 143 \text { amino acids) }\end{array}$ & $\mathrm{Au}$ & l & Fructose & [77] \\
\hline Fructose dehydrogenase & $\mathrm{Au}$ & $\begin{array}{l}\text { Thiol-and diazonium-bound carboxylic } \\
\text { acid }\end{array}$ & Fructose & {$[78]$} \\
\hline Fructose dehydrogenase & Graphite electrode & $\mathrm{Ca}^{2+}$ (used as intracomplexating ions) & Fructose & {$[50]$} \\
\hline D-fructose dehydrogenase & $\begin{array}{l}\text { Graphite } \\
\text { electrode }\end{array}$ & Thermally reduced graphene oxide & Fructose & [79] \\
\hline D-fructose dehydrogenase & $\begin{array}{l}\text { Carbon } \\
\text { electrode }\end{array}$ & Methoxy-aniline derivatives & D-fructose & {$[80]$} \\
\hline Aldehyde dehydrogenases & Glassy carbon & Pyrroloquinoline quinone & $\begin{array}{l}\text { Glucose, } \\
\text { aldehydes }\end{array}$ & [81] \\
\hline
\end{tabular}


Hence, various protocols have been proposed to overcome poor electron transfer communication between the enzymes and electrode [19], including modification of the working electrode surface with nanoparticles [42-43] and application of redox mediators, which can be either dissolved or attached on the electrode surface $[19,44]$. Redox mediators commonly comprise compounds like methylene blue, quinones, hexacyanoferrates, and ferrocene derivatives that are able to shuttle electrons between the working electrode and the active site of the redox enzyme. Most of these protocols are elaborated in detail in [15-21, 45, 46]. All of these studies highlight that "electrostatic compatibility" between the working electrode and the analyzed redox protein is of crucial significance $[5,6,15-19,45]$. The latter improves electron transfer performances and diminishes thermodynamic and kinetic constraints of the electrode reaction. In some cases, polyvalent cations are added into the electrolyte solution, which facilitate electron transfer between the working electrode and enzymes from the group of dehydrogenases and cytochromes, mainly by affecting the orientation of the enzymes [48-50]. The efficiency of electron exchange can be also affected by activation of the so-called "internal electron tunnelling effects" [51]. "Enzymatic tunnels" are parts of the enzymes tertiary structure that are seen as "conductive pathways" between the enzyme redox active site and the working electrode surface. Such "enzymatic tunnels" are often more active in the presence of "foreign" metal cations trapped in the structure of the immobilized enzyme [52].

Besides modification with nanoparticles [19, 21], "functionalization" of the working electrode surface with conductive polymers has been also reported [47, 53]. An especially promising approach seems to be modification with flexible carbon fibers [54]. Authors in [54] designed a powerful "bioelectrode", where nitrated carbon nanoblisters are anchored on the carbon fibers, which are thereafter used to modify the surface of a graphite working electrode. Such approach enabled the study of important enzymes, e.g., glucose dehydrogenase [55]. A very useful review on modifying carbon fibers for various biomedical applications and voltammetric sensor developments is reported in [56]. Hence, the methodology of PFV has been successfully applied for designing highly selective enzymatic sensors, suitable for the detection of important substrates such as hydrogen peroxide [57], glucose [58], superoxide radicals [57, 59], nitrogen oxide [59] and many other physiologically relevant substrates [19]. Following our last review from 2012 [20], Table 1 provides some of the relevant studies published thereafter.

\subsection{Recent theoretical models relevant to protein-film voltammetry}

Considering the complexity of electrode mechanisms of immobilized enzymes, establishing theoretical models for simulation and elucidation of voltammetric behaviour is of particular importance. In recent years, our group [22-35, 37, $38]$ and others $[6,15,36,39,40,82-83]$ have made efforts to understand and predict voltammetric features by studying various theoretical surface electrode mechanisms. It is worth mentioning that theoretical models under conditions of squarewave voltammetry (SWV) are of special interest, as the technique is considered to be the most advanced member in the family of pulse voltammetric techniques $[6,36]$.

A variety of electrode mechanisms have been analyzed theoretically, based on adequate models for surface electrode reactions coupled with chemical reactions. The voltammetric features of a redox enzyme undergoing a one-electron electrode reaction ( $\boldsymbol{E}$ step), coupled with either a preceding or following chemical step ( $\boldsymbol{C}$ step), or by a regenerative follow-up chemical reaction ( $\boldsymbol{C}^{\prime}$ step), are comprehensively studied in the frame of theoretical models for surface $\boldsymbol{C} \boldsymbol{E}[27,84,85], \boldsymbol{E} \boldsymbol{C}$ [27, $30,85]$ and $\boldsymbol{E} \boldsymbol{C}^{\prime}$ [ $[27,33,84,85]$ mechanisms, respectively. These models might be helpful in understanding the voltammetry of cytochromes and other heme-containing proteins, as they undergo redox transformation in a one-electron step [15, 17-19, 21]. In [27, 30, 33, 84, 85], a simple strategy for measuring electrode kinetics is presented, enabling the kinetic characterization of the coupled chemical reactions as well. Especially important insights are obtained in the case of the surface $\boldsymbol{E} \boldsymbol{C}_{\boldsymbol{r}}$ mechanism, i.e. a mechanism in which the product of the electrode reaction is engaged in a chemically reversible follow-up reaction $\left(\boldsymbol{C}_{\boldsymbol{r}}\right.$ step) [25, 27]. This model is closely related to the denaturation of the redox enzymes following the electrode transformation. Although it would be expected that the voltammetric currents would diminish due to the denaturation process, the opposite effect has been predicted under certain conditions in SWV [25, 27]. Specifically, the intensity of the response increases by increasing the rate of the follow-up chemical reaction $\left(\boldsymbol{C}_{\boldsymbol{r}}\right.$ step), in particular when the chemical reaction is associated with moderate kinetics. This peculiar phenomenon is a consequence of the interplay between the rate of the follow-up 
chemical reaction, the chronoamperometric features of the overall electrode mechanism and the specific current-sampling protocol in SWV [25, 27]. It has been shown that the rate of the followup chemical reaction, which proceeds in the time segment of SW potential pulses where the current is not measured, plays a critical role to allow the observation of this feature $[25,30]$. Based on such unique voltammetric behaviour, a simple strategy for complete kinetic and thermodynamic characterization of the surface $\boldsymbol{E C}_{\boldsymbol{r}}$ mechanism has been proposed [25, 27].

Although many enzymes undergo oneelectron redox transformation, it is well known that the redox chemistry of many hydrogenases, peroxidases, enzymes with quinone moieties (flavoproteins), and enzymes containing polyvalent cations of $\mathrm{Co}$, Mo or $\mathrm{W}$ in their redox active site, proceeds via two-electron redox transformation $[15,17,18$, 20, 21]. Thus, surface electrode mechanisms involving two successive one-electron transfer steps is of particular importance ( $\boldsymbol{E} \boldsymbol{E}$ mechanism). Especially complicated situations can exist when one or both of the electrochemical steps are coupled with chemical reactions. If the energies of the two electron transfers differ by at least $200 \mathrm{mV}$ in absolute value, the diagnostic criteria for characterizing each redox step are straightforward [26]. Shown in Figure 3, Figure S1 and Figure S2 are several sets of SW voltammograms of $\boldsymbol{E} \boldsymbol{C E}, \boldsymbol{E E C}$, and $\boldsymbol{E} \boldsymbol{E} \boldsymbol{C}$, mechanisms, respectively. The voltammetric patterns in Figures 3, S1 and S2 represent the influence of the chemical step, i.e. the effect of the substrate concentration in a particular experimental system. In all cases, it is easy to recognize voltammetric features that occur due to the effect of the kinetics of the chemical step, which is in accordance with the expected features reported for the corresponding simpler models [27].

However, when both electron transfers occur at the same potential (or the second step is energetically more favored than the first one), one observes a single SW voltammetric peak which "hides" in its morphology both electron transfer reactions (Fig. 4a). In such a scenario, it is important to find a way to voltammetrically separate the two electron transfer steps, which is possible when the product of the second step is coupled with a follow-up chemical reaction [29]. It has been shown that by altering the kinetics of the follow-up chemical reaction by means of the substrate concentration, the potential of the second electron transfer step can be shifted, resulting in two potentially separated SW voltammetric peaks (Fig. 4d-f).

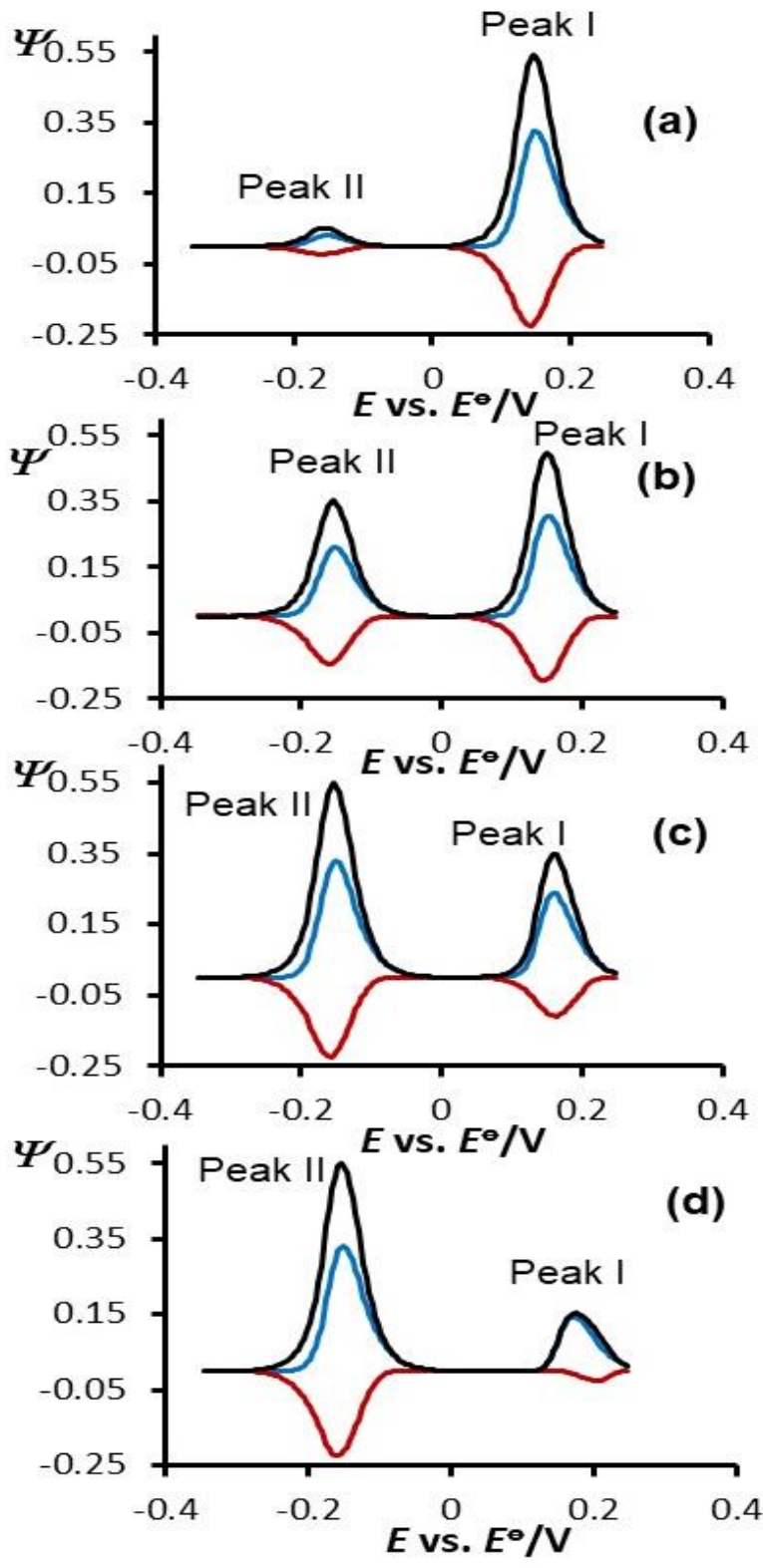

Fig. 3. Surface ECE mechanism $\mathrm{A}(\mathrm{ads})+n_{1} \mathrm{e}-\leftrightarrow \mathrm{B}(\operatorname{ads})+\mathrm{S}$ $\rightarrow \mathrm{C}(\mathrm{ads})+n_{2} \mathrm{e}-\leftrightarrow \mathrm{D}(\mathrm{ads})$ in protein-film voltammetry: effect of the substrate concentration $c(\mathrm{~S})$ to the features of theoretical SW voltammograms. Voltammograms are simulated at a potential separation of $|300 \mathrm{mV}|$ between both electrode steps: The values of $c(\mathrm{~S}) / \mathrm{mol}^{-1^{-1}}$ are set to: 0.001 (a); 0.01 (b); 0.05 (c), and 0.2 (d). The chemical rate constant was set to $k_{\text {chem }}=$ $10 \mathrm{~mol} \cdot \mathrm{l}^{-1} \mathrm{~s}^{-1}$. Magnitudes of dimensionless kinetic parameters of the first $(K \mathrm{I})$ and second $(K \mathrm{II})$ step were $K \mathrm{I}=K \mathrm{II}=0.1$. Other simulation conditions were: SW frequency $f=10 \mathrm{~Hz}$, SW amplitude $E_{\mathrm{sw}}=50 \mathrm{mV}$, potential step $\mathrm{d} E=4 \mathrm{mV}$, temperature $T=298 \mathrm{~K}$. In all simulations, the electron transfer coefficients of the first and second electrode reaction were set to $\alpha=0.5$, while the number of electrons exchanged between the working electrode and the redox adsorbates was $n_{1}=n_{2}=$ 1. The starting potential was set to $+0.25 \mathrm{~V}$ and all scans were run towards negative potentials. All potentials are referred vs the standard redox potential of the first step.

In addition, detailed studies are reported for two-step enzymatic mechanisms coupled with a follow-up [24, 26, 29] reaction, intermediate re- 
generative [26, 33], and preceding [28] chemical steps. While giving diagnostic criteria to recognize a particular mechanism, in $[24,26,28,29,33]$ simple methodologies are proposed for the complete thermodynamic and kinetic characterizations of both electron transfers and coupled chemical reactions. Additional relevant studies related to the voltammetry of two-step enzymatic mechanisms can be found in the works of Komorsky-Lovric and M. Lovric [86-88]
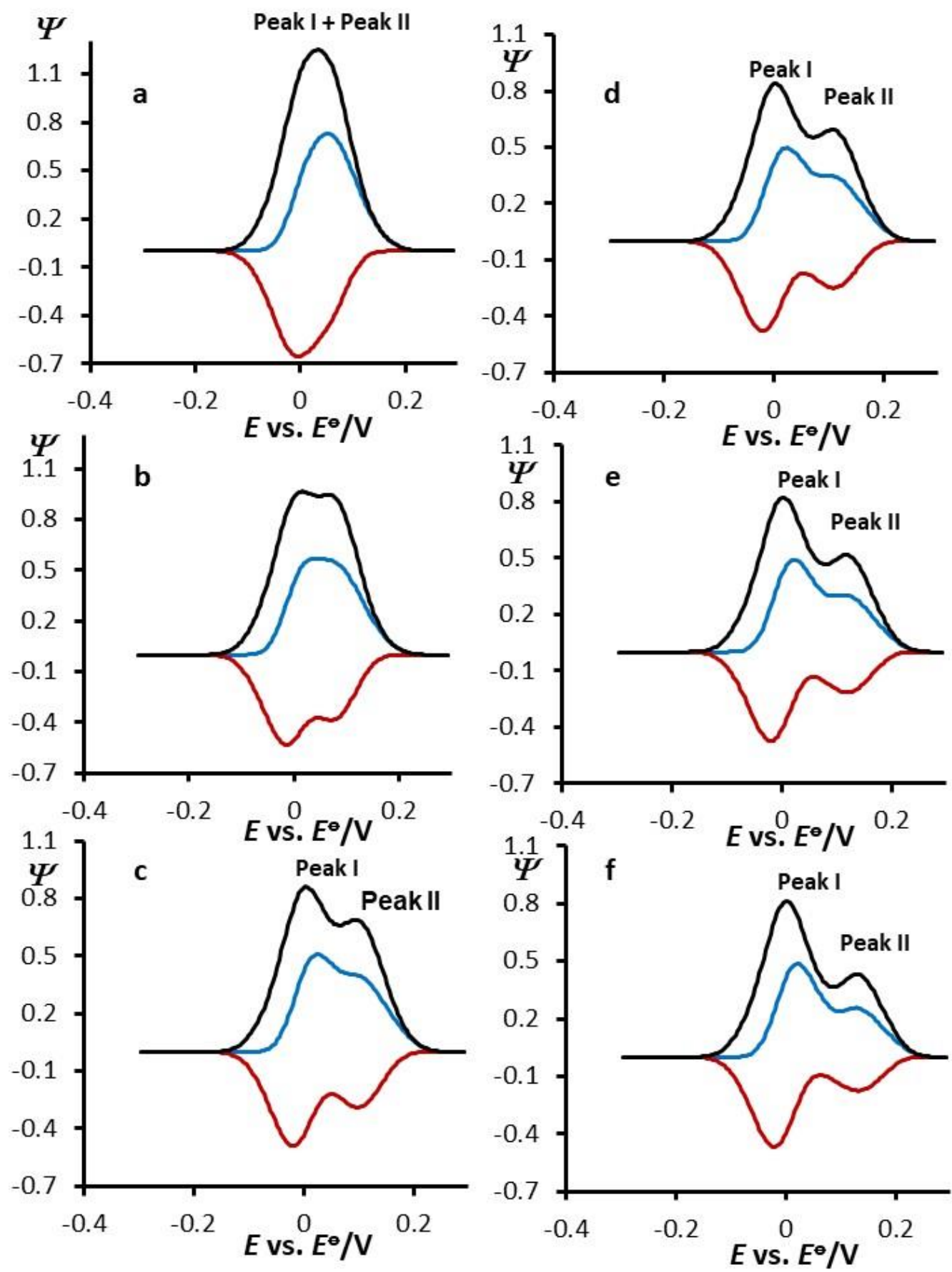

Fig. 4. Surface EEC mechanism $\mathrm{A}(\mathrm{ads})+n_{1} \mathrm{e}-\leftrightarrow \mathrm{B}(\mathrm{ads})+n_{2} \mathrm{e}-\leftrightarrow \mathrm{C}(\mathrm{ads})+\mathrm{S} \leftrightarrow \mathrm{D}(\mathrm{ads})$ in protein-film voltammetry: Effect of the substrate concentration to the features of theoretical SW voltammograms when both electron transfers of an enzyme redox transformation take place at the same potential. The values of $c(\mathrm{~S}) / \mathrm{mol} \cdot \mathrm{l}^{-1}$ are set to: 0.0001 (a); 0.02 (b); 0.04 (c); 0.05 (d); 0.06 (e), and 0.075 (f). $K \mathrm{I}=1.25 ; K \mathrm{II}=2.80$. The value of the chemical rate constant was set to $k_{\mathrm{chem}}=10 \mathrm{~mol} \cdot \mathrm{l}^{-1} \mathrm{~s}^{-1}$. The equilibrium constant of the follow-up chemical reaction was $K_{\text {eq }}=0.1$. All other simulation parameters were the same as those in Figure 3. 


\subsection{Outlooks for the future}

Probing the electrochemical reactions of enzymes offers unprecedented insight into the dynamic properties of these important biocatalysts and their application in various fields related to biosensing and energy conversion systems. Although PFV is probably the simplest experimental set-up designed to study the electrochemi$\mathrm{cal} /$ chemical features of redox proteins, this methodology still suffers from many drawbacks. Major obstacles are seen in the denaturation of the redox proteins and especially in poor electron transfer communication between the working electrode and the active site(s) of analyzed enzymes. To overcome these obstacles, so-called "functionalization" of the working electrode surface must be performed. The modification of electrode surfaces with various conductive polymers and nanoparticles seem to be inevitable scenarios to achieve better compatibility for many electrode-enzyme systems. Indeed, the number of redox enzymes that are suitable for use with PFV is still limited to several hydrogenases, flavoproteins and some metalloenzymes containing ions of $\mathrm{Fe}, \mathrm{Cu}, \mathrm{Co}$, Mo or $\mathrm{W}$. Even with modification of the working electrode surface, many dynamic features of the enzymatic turnover are still inaccessible by conventional PFV experiments. A promising scenario to overcome some of these drawbacks is seen in the "single molecule" enzymatic studies [89]. This is of exceptional importance, if such systems are studied at a single nanoparticle entity [90-93]. In such an approach, the extraction of kinetic parameters and information on the enzymes mechanism in its natural environment should enable the development of miniaturized voltammetric biosensors. These can be further explored for the detection and quantification of various biomarkers. This can be considered as one of the biggest challenges of PFV methodology applied to biomedicine. For fast and precise kinetic determination of enzymatic systems at molecular levels and to achieve better analytical sensitivity, some of the recent methodological studies might be helpful [31, 35, 94--98].

In this context, it is worth mentioning several novel chronoamperometric and voltammetric techniques, derived from the perspective of SWV, which bear potential for improved electrochemical study in the context of PFV. One example is "electrochemical faradaic spectroscopy" [97], which utilizes a pulse form of a chronoamperometric experiment that is highly promising in the analytical application of PFV as well as in the development of electrochemical sensors (Fig. 5).
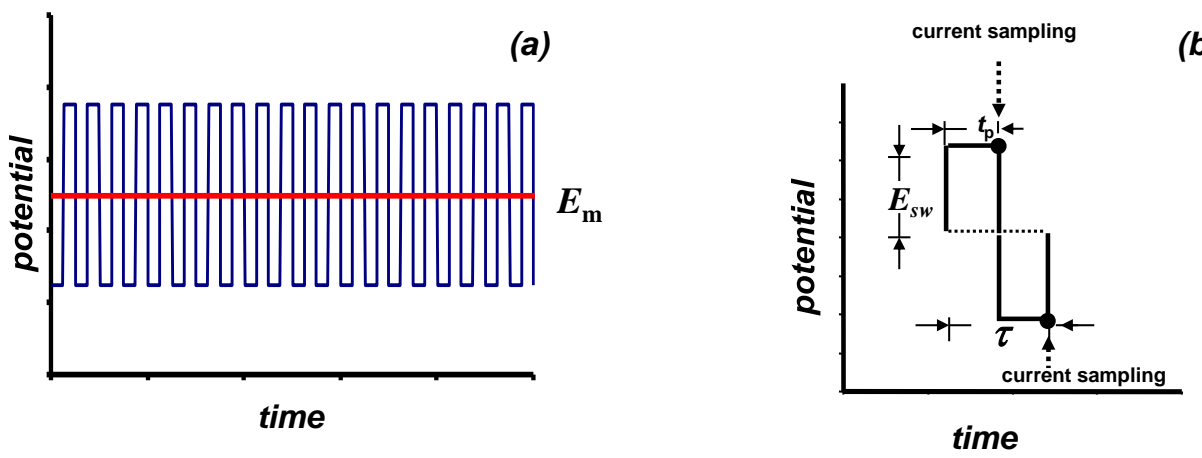

(b)
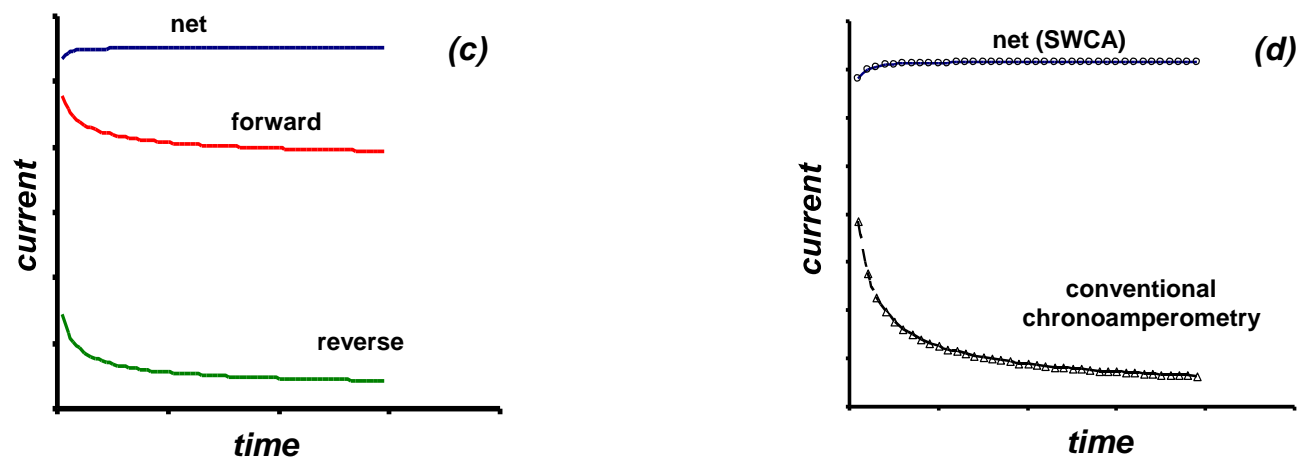

Fig. 5. $S W$ chronoamperometry ( $S W C A$ ). (a) Scheme of the excitation signal consisting of a constant mid-potential $\left(E_{\mathrm{m}}\right)$ upon which, small, oppositely oriented potential pulses are imposed, analogous to conventional SWV. (b) Defining parameters of single squarewave potential cycle, with meaninig identical as in SWV. (c) Current responses of this technique have the shape of a square-wave chronoamperogram, showing forward, reverse and net current components as a function of experiment time. (d) A comparison of the chronoamperometric response of the technique with the conventional chronoamperometry. 
The technique, which can be also termed as "square-wave chronoamperometry", is superior in sensitivity compared to both conventional chronoamperometry and SWV. From the plethora of novel voltammetric techniques, we recall recent techniques such as "differential square-wave voltammetry" [31], "double-sampled differential square-wave voltammetry" [98] and "multisampling square-wave voltammetry" [96]. In differential square-wave voltammetry (Fig. 6), inherent advantages of differ- ential pulse and SWV are unified for the purpose of better discrimination against both charging and background current, while maintaining the ability for the mechanistic and kinetic study of electrode reactions. Differential variants of SWV can also be achieved by introducing a double sampling current protocol, as depicted in Figure 7. This technique is expected to improve mechanistic and kinetic analysis of electrode processes at any degree of electrochemical reversibility [98].
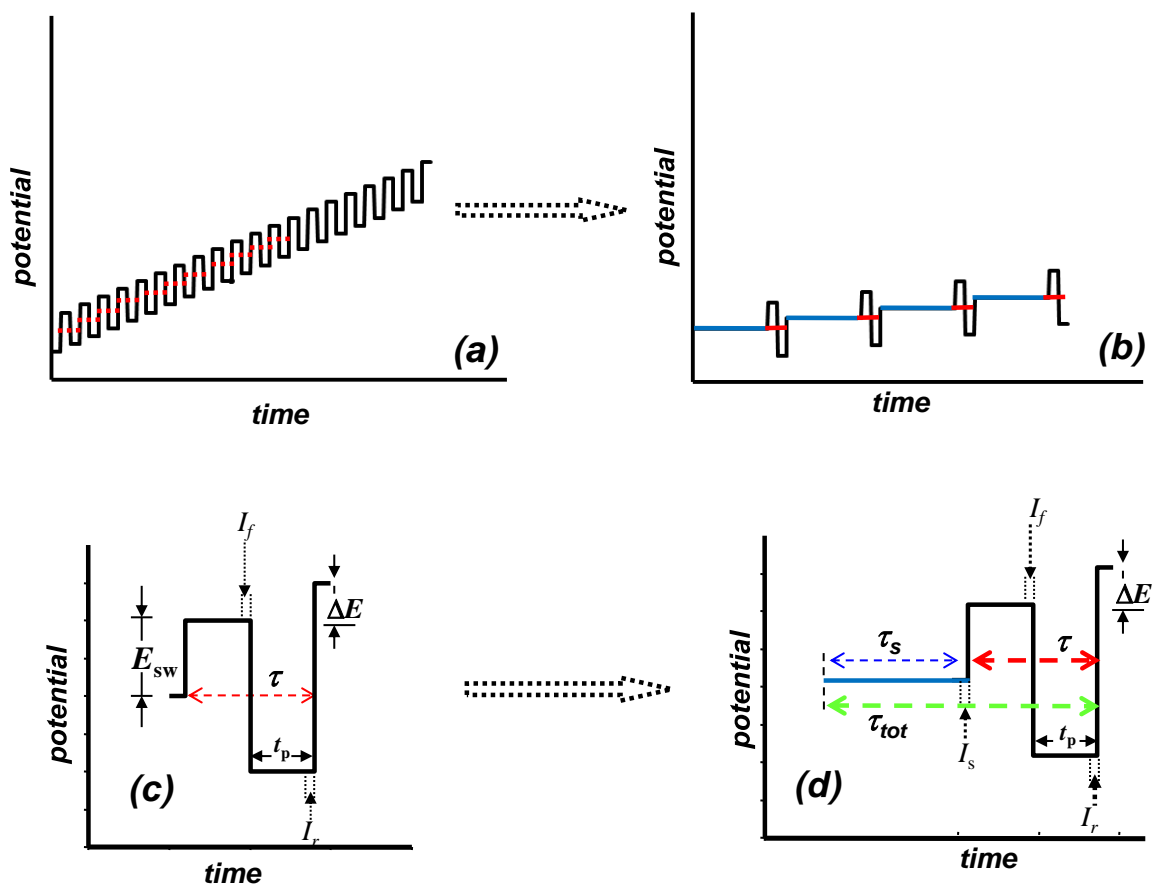

Fig. 6. Potential modulation in (a) conventional SWV and (b) a new, hybrid technique termed as differential square-wave voltammetry (DSWV). (c) Single square-wave potential cycle in SWV, showing the duration of a potential cycle $(\tau)$ and the single potential pulse $\left(t_{\mathrm{p}}\right)$, the height of the pulse, i.e. SW amplitude $\left(E_{\mathrm{sw}}\right)$, the step potential $(\Delta \mathrm{E})$ and current sampling points (forward $\left(I_{\mathrm{f}}\right)$ and reverse current $\left.\left(I_{\mathrm{r}}\right)\right)$. (d) Single potential cycle of DSWV including an additional time of the step potential $\left(\tau_{\mathrm{s}}\right)$ and three current sampling points: $I_{\mathrm{s}}, I_{\mathrm{f}}$ and $I_{\mathrm{r}}$, referring to the current measured at the end of the potential step, the forward potential pulse and reverse potential pulse, respectively.
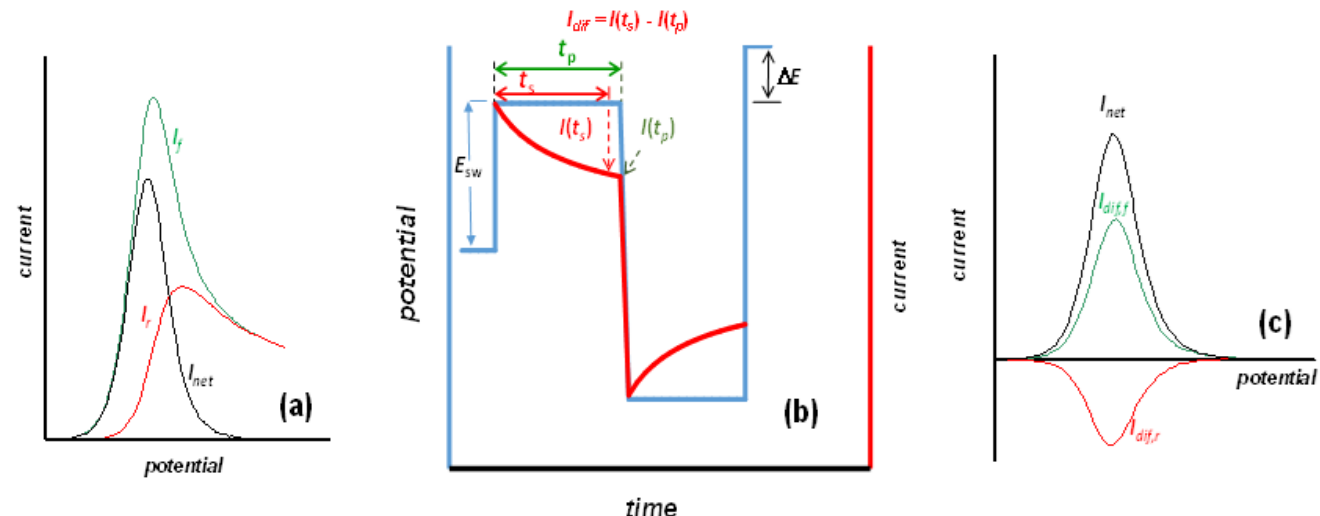

Fig. 7. (a) Current responses of a sluggish redox reaction in conventional SWV. (b) Single potential cycle in SWV showing the variation of the potential (blue line, left ordinate) and current (red line, right ordinate) with time. The current is sampled twice in the last quarter of each potential pulse at times $t_{\mathrm{s}}$ and $t_{\mathrm{p}}$, and the differential current $I_{\mathrm{dif}}=I\left(\mathrm{t}_{\mathrm{s}}\right)-I\left(\mathrm{t}_{\mathrm{p}}\right)$ for each potential pulse is calculated. (c) Expected current responses of a sluggish redox reaction under double-sampling square-wave voltammetry (DSSWV) consisting of differential forward, reverse and net current components. 
The idea of the double-sampling current protocol can be further expanded for the purpose of fast characterization of electrode processes [98]. In regards to this goal, SWV is considered as a complex, repetitive double-step chronoamperometric experiment, which provides current-time-potential information in the course of a single experiment (Fig. 8). A typical outcome, presented in a current-time domain (Fig. 8 panel $b$ ) reveals a wealth of electro-

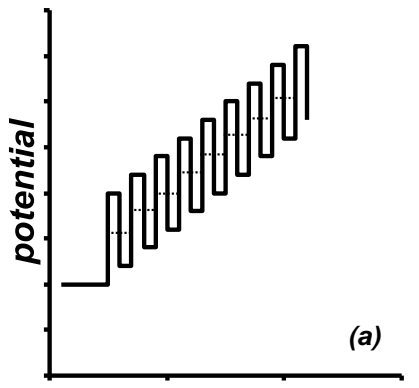

time chemical data. Applying a multisampling current procedure at different sampling times $\left(t_{\mathrm{s}}\right)$, (Fig. 8 panel $c$ ), several multi-sampled SW voltammograms can be constructed. Hence, out of a single experiment, a series of SW voltammograms can be constructed, the analysis of which can reveal both electrode kinetics and mechanisms. This is highly relevant in the context of enzymatic analysis and sensor applications of voltammetry in biomedicine.

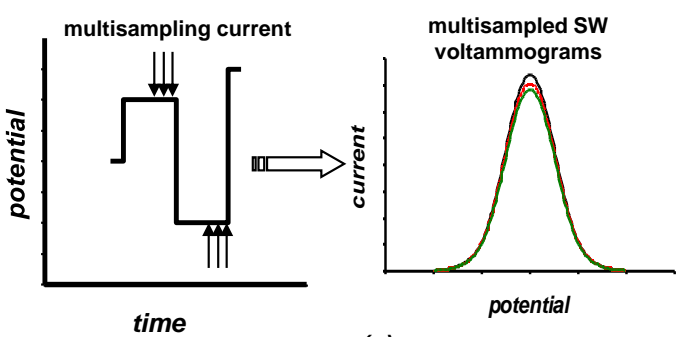

(c)

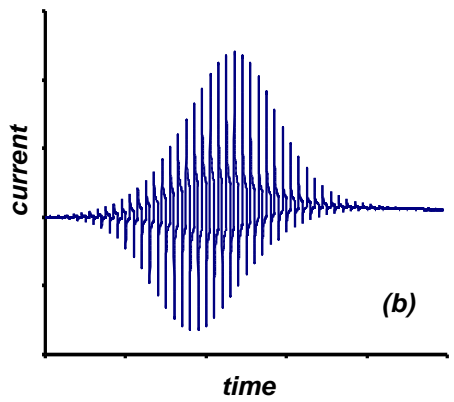

Fig. 8. (a) Potential waveform and (b) variation of the current with time, considering SWV as a complex repetitive double-step chronoamperometric experiment. (c) Current sampling points at different times of each potential pulse and corresponding multi-sampled net SW voltammograms.

Acknowledgment: Valentin Mirčeski acknowledges with gratitude the support through the NATO Grant No. SPS G5550. Rubin Gulaboski thanks the Ministry of Science and Education of the Republic of Macedonia and the Goce Delčev University in Štip for their support. We also thank MSci Leon Stojanov for his help during preparation of this work.

\section{REFERENCES}

[1] G. Dryhurst, Electrochemistry of Biological Molecules, Academic Press, New York, 2012.

[2] S. Cosnier, Electrochemical Biosensors, Jenny Stanford Publishing, Singapore, 2015.

[3] R. C. Alkire, D. M. Kolb, K. Lipkowski, Bioelectrochemistry: Fundamentals, Applications and Recent Developments, New Jersey, Wiley-VCH, 2011.

[4] A. J. Bard, L. R. Faulkner, Electrochemical Methods: Fundamentals and Applications. $2^{\text {nd }}$ ed., Wiley, New York, 2001.
[5] J-M. Savéant, Jean-Michel, Elements of Molecular and Biomolecular Electrochemistry: An Electrochemical Approach to Electron Transfer Chemistry, John Wiley \& Sons, 2006.

[6] R. G. Compton, C. E. Banks, Understanding Voltammetry, $3^{\text {rd }}$ edition, World Scientific Publishing Europe Ltd, UK, 2018.

[7] A. D. Rodriguez, Drug-Drug Interactions, CRC Press, London, UK, 2019.

[8] R. Das, M. Das, S. R. Chinnadayyala, I. M. Singha, P. Goswami, Recent advances on developing $3^{\text {rd }}$ generation enzyme electrode for biosensor applications, Biosens. Bioelectron., 79, 386-397 (2016). DOI: 10.1016/j.bios.2015.12.055

[9] R. Islam, H. T. L. Luu, S. Kuss, ReviewElectrochemical approaches and advances towards detection of drug resistance, J. Electrochem. Soc. 167, 045501 (2020).

https://iopscience.iop.org/article/10.1149/1945-7111/ab6ff3 
[10] R. Gulaboski, P. Kokoskarova, S. Petkovska, Analysis of drug-drug interactions with cyclic voltammetry-an overview of relevant theoretical models and recent experimental achievments, Anal. Bioanal. Electrochem., 12, 345-364 (2020).

http://www.abechem.com/article_43201.html

[11] I. Taurino, G. Sanzò, R. Antiochia, C. Tortolini, F. Mazzei, G. Favero, G. De Micheli, S. Carrara, Recent advances in third generation biosensors based on $\mathrm{Au}$ and Pt nanostructured electrodes, Trends Anal. Chem., 79, 151-159 (2016).

https://doi.org/10.1016/j.trac.2016.01.020

[12] P. Yanez-Sedeno, S. Campuzano, J. M. Pingarron, Carbon nanostructures for tagging in electrochemical biosensing: A review, J. Carbon Res., 3 (2017). DOI: doi.org/10.3390/c3010003.

[13] T. A. Silva, F. C. Moraes, B. C. Janegitz, O. FatibelloFilho, Electrochemical biosensors based on nanostructured carbon black: A review, J. Nanomater., 4571614 (2017). DOI: doi.org/10.1155/2017/4571614

[14] P. Bollella, C. Schulz, G. Favero, F. Mazzei, R. Ludwig, L. Gorton, R. Antiochia, Green synthesis and characterization of gold and silver nanoparticles and their application for development of a third generation lactose biosensor, Electroanal., 29, 77-86 (2017). https://doi.org/10.1002/elan.201600476

[15] C. Leger, P. Bertrand, Direct electrochemistry of redox enzymes as a tool for mechanistic studies, Chem. Rev., 108, 2379-2438 (2007). DOI: doi.org/10.1021/cr0680742

[16] L. Jeuken. Biophotoelectrochemistry: from Bioelectrochemistry to Biophotovoltaics, Springer International, Switzerland, 2016.

[17] F. A. Armstrong, H. A. Heering, J. Hirst, Reactions of complex metalloproteins studied by protein-film voltammetry, Chem. Soc. Rev., 26, 169-179 (1997). DOI: $10.1039 / \mathrm{CS} 9972600169$

[18] F. A. Armstrong, Insights from protein film voltammetry into mechanisms of complex biological electron-transfer reactions, J. Chem. Soc. Dalton. Trans., 5, 661-671 (2002).

[19] P. Bollella, E. Katz, Enzyme-based biosensors: Tackling electron transfer issues, Sensors, 20, 3517 (2020). DOI: $10.3390 / \mathrm{s} 20123517$

[20] R. Gulaboski, V. Mirceski, I. Bogeski, M. Hoth, Protein film voltammetry-electrochemical enzymatic spectroscopy. A review on recent progress, J. Solid State Electrochem., 16, 2315-2328 (2012). https://doi.org/10.1007/s10008-011-1397-5

[21] P. Bartlett, Bioelectrochemistry: Fundamentals, Experimental Techniques and Applications, J Wiley \& Sons, New Jersey, 2008.

[22] R. Gulaboski, P. Kokoskarova, S. Mitrev, Theoretical aspects of several successive two-step redox mechanisms in protein-film cyclic staircase voltammetry, Electrochim. Acta, 69, 86-96 (2012). DOI: $10.1016 /$ j.electacta.2012.02.086

[23] R. Gulaboski, P. Kokoskarova, S. Petkovska, Timeindependent methodology to access Michaelis-Menten constant by exploring electrochemical-catalytic mecha- nism in protein-film cyclic staircase voltammetry, Croat. Chem. Acta, 91, 377-382 (2018).

DOI: $10.5562 /$ cca3383

[24] P. Kokoskarova, M. Janeva, V. Maksimova, R. Gulaboski, Protein-film Voltammetry of two-step electrode enzymatic reactions coupled with an irreversible chemical reaction of a final product-a theoretical study in square-wave voltammetry, Electroanal., 31, 1454-1464 (2019). DOI: 10.1002/elan.20190022

[25] R. Gulaboski, M. Janeva, V. Maksimova, New aspects of protein-film voltammetry of redox enzymes coupled to follow-up reversible chemical reaction in square-wave voltammetry, Electroanal., 31, 946-956 (2019). https://doi.org/10.1002/elan.201900028

[26] M. Janeva, P. Kokoskarova, V. Maksimova, R. Gulaboski, Square-wave voltammetry of two-step surface redox mechanisms coupled with chemical reactions - a theoretical overview, Electroanal., 31, 2488-2506 (2019). DOI: doi/10.1002/elan.201900416

[27] R. Gulaboski, V. Mirceski, M. Lovric, Square-wave protein-film voltammetry: new insights in the enzymatic electrode processes coupled with chemical reactions, $J$. Solid State Electrochem., 23, 2493-2506 (2019). https://doi.org/10.1007/s10008-019-04320-7

[28] M. Janeva, P. Kokoskarova, R. Gulaboski, Multistep surface electrode mechanism coupled with preceding chemical reaction-theoretical analysis in square-wave voltammetry, Anal. Bioanal. Electrochem., 12, 766-779 (2020).

[29] R. Gulaboski, V. Mirceski, Simple voltammetric approach for characterisation of two-step surface electrode mechanism in protein-film voltammetry, J. Solid State Electrochem., 24 (2020).

https://link.springer.com/article/10.1007/s10008-02004563-9

[30] R. Gulaboski, Theoretical contribution towards understanding specific behaviour of "simple" protein-film reactions in square-wave voltammetry. Electroanal., 31, 545-553 (2019).

https://onlinelibrary.wiley.com/doi/10.1002/elan.201800 739

[31] V. Mirceski, D. Guziejewski, L Stojanov, R. Gulaboski, Differential square-wave voltammetry, Anal. Chem., 91, 4904-14910 (2019). https://doi.org/10.1021/acs.analchem.9b03035

[32] P. Kokoskarova, R. Gulaboski, Theoretical aspects of a surface electrode reaction coupled with preceding and regenerative chemical steps: Square-wave voltammetry of a surface CEC' mechanism, Electroanal., 32, 333344 (2020). https://doi.org/10.1002/elan.201900491

[33] R. Gulaboski, V. Mirceski, New aspects of the electrochemical-catalytic (EC') mechanism in square-wave voltammetry, Electrochim. Acta, 167, 219-225 (2015). https://doi.org/10.1016/j.electacta.2015.03.175

[34] V. Mirceski, R. Gulaboski, Recent achievements in square-wave voltammetry (a review), Maced. J. Chem. Chem. Eng., 33, 1-12 (2014).

[35] V. Mirceski, D. Guzijewski, R. Gulaboski, Electrode kinetics from a single square-wave voltammograms, Maced. J. Chem. Chem. Eng. 34, 181-188 (2015). 
[36] A. Molina, J. Gonzales, Pulse voltammetry in physical electrochemistry and electroanalysis. In: Monographs in Electrochemistry (F. Scholz, ed.), Springer, Berlin Heidelberg, 2016.

[37] R. Gulaboski, L. Mihajlov, Catalytic mechanism in successive two-step protein-film voltammetry - theoretical study in square-wave voltammetry, Biophys. Chem., 155, 1-9 (2011). https://doi.org/10.1016/j.bpc.2011.01.010

[38] S. Petkovska, R. Gulaboski, Theoretical analysis of a surface catalytic mechanism associated with reversible chemical reaction under conditions of cyclic staircase voltammetry, Electroanal., 32, 992-1004 (2020). https://doi.org/10.1002/elan.201900698

[39] M. A. Mann, L. A. Bottomley, Cyclic square-wave voltammetry of surface-confined quasireversible electron transfer reactions, Langmuir, 31, 9511-9520 (2015). https://doi.org/10.1021/acs.langmuir.5b01684

[40] C. B. McAuley, E. Katelhon, E. O. Barnes, R. G. Compton, E. Laborda, A. Molina, Recent advances in voltammetry, Chem. Open, 4, 224-260 (2015). DOI: 10.1002/open.201500042

[41] W. Putzbach, N. J. Ronkainen, Immobilization techniques in the fabrication of nanomaterial-based electrochemical biosensors: A review, Sensors, 13, 4811-4840 (2013). https://doi.org/10.3390/s 130404811

[42] P. Bollella, Porous gold: A new frontier for enzymebased electrodes. Nanomaterials, 10, 722 (2020). https://doi.org/10.3390/nano10040722

[43] P. Bollella, F. Mazzei, G. Favero, G. Fusco, R. Ludwig, L. Gorton, R. Antiochia, Improved DET communication between cellobiose dehydrogenase and a gold electrode modified with a rigid self-assembled monolayer and green metal nanoparticles: The role of an ordered nanostructuration, Biosens. Bioelectron., 88, 196-203 (2017). DOI: 10.1016/j.bios.2016.08.027

[44] P. Avanagh, D. Leech, Mediated electron transfer in glucose oxidising enzyme electrodes for application to biofuel cells: recent progress and perspectives, Phys. Chem. Chem. Phys., 15, 4859-4869 (2013). DOI: $10.1039 / \mathrm{c} 3 \mathrm{cp} 44617 \mathrm{~d}$

[45] C. Léger, S. J. Elliott, K. R. Hoke, L. J. C. Jeuken, A. K. Jones and F. A. Armstrong, Enzyme electrokinetics: Using protein film voltammetry to investigate redox enzymes and their mechanisms, Biochemistry, 42, 86538662 (2003). https://doi.org/10.1021/bi034789c

[46] G. Li, P. Miao, Electrochemical Analysis of Proteins and Cells, Springer Science and Business Media, 2012.

[47] F. A. Al-Lolage, M. Meneghello, S. Ma, R. Ludwig, P. N. Bartlett, A flexible method for the stable, covalent immobilization of enzymes at electrode surfaces, ChemElectroChem, 4, 1528-1534 (2017). https://doi.org/10.1002/celc.201700135

[48] C. Schulz, R. Ludwig, P. O. Micheelsen, M. Silow, M. D. Toscano, L. Gorton, Enhancement of enzymatic activity and catalytic current of cellobiose dehydrogenase by calcium ions, Electrochem. Commun., 17, 71-74 (2012).

https://doi.org/10.1016/j.elecom.2012.01
[49] D. Kracher, K. Zahma, C. Schulz, C. Sygmund, L. Gorton, R. Ludwig, Inter-domain electron transfer in cellobiose dehydrogenase: Modulation by $\mathrm{pH}$ and divalent cations, FEBS J., 282, 3136-3148 (2015).

DOI: $10.1111 /$ febs.13310

[50] P. Bollella, Y. Hibino, K. Kano, L. Gorton, R. Antiochia, The influence of $\mathrm{pH}$ and divalent/monovalent cations on the internal electron transfer (IET), enzymatic activity, and structure of fructose dehydrogenase, Anal. Bioanal. Chem., 410, 3253-3264 (2018).

[51] J. R. Winkler, H. B. Gray, Long-range electron tunneling, J. Am. Chem. Soc., 136, 2930-2939 (2014). https://doi.org/10.1021/ja500215j

[52] G. Li, P. Yao, R. Gong, J. Li, P. Liu, R. Lonsdale, Q. Wu, J. Lin, D. Zhu, M. T. Reetz, Simultaneous engineering of an enzyme's entrance tunnel and active site: the case of monoamine oxidase MAO-N, Chem. Sci., 8, 4093-4099 (2017). DOI: 10.1039/c6sc05381e

[53] A. Ruff, Redox polymers in bioelectrochemistry: Common playgrounds and novel concepts. Curr. Opin. Electrochem., 5, 66-73 (2017). https://doi.org/10.1016/j.coelec.2017.06.007

[54] A. R. Pereira, J. C. P. de Souza, R. M. Iost, F. C. P. F. Sales, F. N. Crespilho, Application of carbon fibers to flexible enzyme electrodes, J. Electroanal. Chem., 780, 396-406 (2016). https://doi.org/10.1016/j.jelechem.2016.01.004

[55] J. C. P. de Souza, R. M. Iost, F. N. Crespilho, Nitrated carbon nanoblisters for high-performance glucose dehydrogenase bioanodes, Biosens Bioelectron, 77, 860-865 (2016). DOI: 10.1016/j.bios.2015.08.069

[56] R. M. Kakhki, A review to recent developments in modification of carbon fiber electrodes, Arab. J. Chem., 12, 1783-1794 (2019). https://doi.org/10.1016/j.arabjc.2019.01.006

[57] R. Gulaboski, V. Mirceski, R. Kappl, M. Hoth, M. Bozem, Quantification of hydrogen peroxide by electrochemical methods and electron spin resonance spectroscopy, J. Electrochem. Soc., 166, G82-G101 (2019). DOI: $10.1149 / 2.1061908$ jes

[58] P. Bollella, L. Gorton, R. Ludwig, R. Antiochia, A third generation glucose biosensor, based on cellobiose dehydrogenase immobilized on a glassy carbon electrode decorated with electrodeposited gold nanoparticles: Characterization and application in human saliva, Sensors, 17, 1912 (2017). DOI: 10.3390/s17081912

[59] S. Prabhulkar, H. Tian, X. Wang, J-J. Zhu, C-Z. Li, Engineered proteins: redox properties and their application, Antioxid. Redox Signal., 17, 1796-1822 (2012). DOI: $10.1089 /$ ars.2011.4001

[60] S. Ma, C. V. Laurent, M. Meneghello, J. Tuoriniemi, C. Oostenbrink, L. Gorton, P. N. Bartlett, R. Ludwig, Direct electron-transfer anisotropy of a site-specifically immobilized cellobiose dehydrogenase, ACS Catal. 9, 7607-7615 (2019). https://doi.org/10.1021/acscatal.9b02014

[61] S. Bozorgzadeh, H. Hamidi R. Ortiz, R. Ludwig, L. Gorton, Direct electron transfer of Phanerochaete chrysosporium cellobiose dehydrogenase at platinum and palladium nanoparticles decorated carbon nanotubes 
modified electrodes, Phys. Chem. Chem. Phys., 17, 24157-24165 (2015). DOI: 10.1039/C5CP03812J.

[62] M. Tavahodi, R. Ortiz, C. Schulz, A. Ekhtiari, R. Ludwig, B. Haghighi, L. Gorton, Direct electron transfer of cellobiose dehydrogenase on positively charged polyethyleneimine gold nanoparticles, Chem. Plus Chem., 82, 546-552 (2017). DOI: $10.1002 /$ cplu.201600453

[63] M. Meneghello, F. A. Al-Lolage, S. Ma, R. Ludwig, P. N. Bartlett, Studying direct electron transfer by sitedirected immobilization of cellobiose dehydrogenase. ChemElectroChem, 6, 700-713 (2019). https://doi.org/10.1002/celc.201801503

[64] F. A. Al-Lolage, P. N. Bartlett, S. Gounel, P. Staigre, N. Mano, Site-directed immobilization of bilirubin oxidase for electrocatalytic oxygen reduction, ACS Catal. 9, 2068-2078 (2019). https://doi.org/10.1021/acs.chemrev.9b00115

[65] A. de Poulpiquet, C. H. Kjaergaard, J. Rouhana, I. Mazurenko, P. Infossi, S. Gounel, R. Gadiou, M. T. Giudici-Orticoni, E. I. Solomon, N. Mano, Mechanism of chloride inhibition of bilirubin oxidases and its dependence on potential and $\mathrm{pH}$, ACS Catal., 7, 3916-3923 (2017). https://doi.org/10.1021/acscatal.7b01286

[66] N. Suzuki, J. Lee, N. Loew, Y. Takahashi-Inose, J. Okuda-Shimazaki, K. Kojima, K. Mori, W. Tsugawa, K. Sode, Engineered glucose oxidase capable of quasidirect electron transfer after a quick-and-easy modification with a mediator, Int. J. Mol. Sci., 21, 1137 (2020). DOI: $10.3390 /$ ijms 21031137

[67] P. Bollella, S. Sharma, A. E. G. Cass, R. Antiochia, Minimally-invasive microneedle-based biosensor array for simultaneous lactate and glucose monitoring in artificial interstitial fluid, Electroanal., 31, 374-382 (2019). DOI: doi.org/10.1002/elan.201800630

[68] V. Flexer, N. Mano, Wired pyrroloquinoline quinone soluble glucose dehydrogenase enzyme electrodes operating at unprecedented low redox potential, Anal. Chem., 86, 2465-2473 (2014). DOI: 10.1021/ac403334w.

[69] I. Algov, J. Grushka R. Zarivach L. Alfonta, Highly efficient flavin-adenine dinucleotide glucose dehydrogenase fused to a minimal cytochrome $c$ domain, J. Am. Chem. Soc., 139, 17217-17220 (2017). DOI: $10.1021 /$ jacs.7b07011

[70] J. H. Luong, J. D. Glennon, A. Gedanken, S. K. Vashist, Achievement and assessment of direct electron transfer of glucose oxidase in electrochemical biosensing using carbon nanotubes, graphene, and their nanocomposites. Microchim. Acta, 184, 369-388 (2017). https://doi.org/10.1007/s00604-016-2049-3

[71] Y. F. Bai, T. B. Xu, J. H. Luong, H. F. Cui, Direct electron transfer of glucose oxidase-boron doped diamond interface: A new solution for a classical problem, Anal. Chem., 86, 4910-4918 (2014). https://doi.org/10.1021/ac501143e

[72] A. Killyeni, M. E. Yakovleva, D. MacAodha, P. O. Conghaile, C. Gonaus, R. Ortiz, D. Leech, I. C. Popescu, C. K. Peterbauer, L. Gorton, Effect of deglycosylation on the mediated electrocatalytic activity of recombinantly expressed Agaricus meleagris pyranose dehydrogenase wired by osmium redox polymer, Electrochim. Acta, 126, 61-67 (2014). https://doi.org/10.1016/j.electacta.2013.08.069
[73] K. Reddaiah, T. M. Reddy, Electrochemical biosensor based on silica sol-gel entrapment of horseradish peroxidase onto the carbon paste electrode toward the determination of 2-aminophenol in non-aqueous solvents: A voltammetric study, J. Mol Liq., 196, 77-85 (2014). https://doi.org/10.1016/j.molliq.2014.03.023

[74] M. V. A. Martins, A. R. Pereira, R. A. S. Luz, R. M. Iost, F. N. Crespilho, Evidence of short-range electron transfer of a redox enzyme on graphene oxide electrodes, Phys. Chem. Chem. Phys., 16, 17426-17436 (2014). https://doi.org/10.1039/C4CP00452C

[75] M. Sosna, A. Bonamore, L. Gorton, A. Boffi, E. E. Ferapontova, Direct electrochemistry and Os-polymermediated bioelectrocatalysis of NADH oxidation by Escherichia coli flavohemoglobin at graphite electrodes. Biosens. Bioelectron., 42, 219-224 (2013). DOI: 10.1016/j.bios.2012.10.094.

[76] K. So, S. Kawai, Y. Hamano, Y. Kitazumi, O. Shirai, M. Hibi, J. Ogawa, K. Kano, Improvement of a direct electron transfer-type fructose/dioxygen biofuel cell with a substrate-modified biocathode., Phys. Chem. Chem. Phys., 16, 4823-4829 (2014).

DOI: $10.1039 / \mathrm{c} 3 \mathrm{cp} 54888 \mathrm{k}$

[77] Y. Hibino, S. Kawai, Y. Kitazumi, O. Shirai, K. Kano, Construction of a protein-engineered variant of Dfructose dehydrogenase for direct electron transfer-type bioelectrocatalysis, Electrochem. Commun., 77, 112 115 (2017). DOI: 10.1016/j.elecom.2017.03.005

[78] T. Siepenkoetter, U. Salaj-Kosla, E. Magner, The immobilization of fructose dehydrogenase on nanoporous gold electrodes for the detection of fructose, Chem. Electro. Chem., 4, 905-912 (2017). DOI: $10.1002 /$ celc. 201600842

[79] I. Sakinyte, J. Barkauskas, J. Gaidukevic, J. Razumiene, Thermally reduced graphene oxide: The study and use for reagentless amperometric D-fructose biosensors, $\mathrm{Ta}$ lanta, 144, 1096-1103 (2015). DOI: 10.1016/j.talanta.2015.07.072

[80] H.-Q. Xia, Y. Hibino, Y. Kitazumi, O. Shirai, K. Kano, Interaction between D-fructose dehydrogenase and methoxy-substituent-functionalized carbon surface to increase productive orientations, Electrochim. Acta, 218, 41-46 (2016). DOI: 10.1016/j.electacta.2016.09.093

[81] S. Xu, S. D. Minteer, Investigating the impact of multiheme pyrroloquinoline quinone-aldehyde dehydrogenase orientation on direct bioelectrocatalysis via site specific enzyme immobilization, ACS Catal., 3, 1756-1763 (2013). DOI: 10.1021/cs400316b.

[82] Y. B. Vogel, A. Molina, J. Gonzalez, S. Ciampi, Quantitative analysis of cyclic voltammetry of redox monolayers adsorbed on semiconductors: Isolating electrode kinetics, lateral interactions and diode currents, Anal. Chem. 91, 5929-5937 (2019). https://doi.org/10.1021/acs.analchem.9b00336

[83] J. Gonzalez, J. A. Sequi, Influence of intermolecular interactions in the redox kinetics performance of surface confined probes by square-wave voltammetry, J. Electroanal. Chem., 854, 113549 (2019). DOI: $10.1016 /$ j.jelechem.2019.113549

[84] R. Gulaboski, V. Mirceski, M. Lovric, I. Bogeski, Theoretical study of a surface electrode reaction preceded by a homogeneous chemical reaction under conditions of 
square-wave voltammetry, Electrochem. Commun., 7, 515-522 (2005).

https://doi.org/10.1016/j.elecom.2005.03.009

[85] V. Mirceski, S. Komorsky-Lovric, M. Lovric, Squarewave voltammetry Theory and application. In Monographs in Electrochemistry, (F. Scholz, ed.), Springer, Berlin, 2007.

[86] S. Komorsky-Lovric, M. Lovric, Simulation of squarewave voltammograms of three-electron redox reaction, Electrochim. Acta, 56, 7189-7193 (2012). https://doi.org/10.1016/j.electacta.2011.05.002

[87] S. Komorsky-Lovric, M. Lovric, Theory of square-wave voltammetry of two-step electrode reaction with kinetically stabilized intermediate, J. Electroanal. Chem., 660, 22-25 (2011). https://doi.org/10.1016/j.jelechem.2011.05.026

[88] S. Komorsky-Lovric, M. Lovric, Theory of square-wave voltammetry of two electron reduction with the intermediate that is stabilized by complexation, Electrochim. Acta, 69, 60-64 (2012). https://doi.org/10.1016/j.electacta.2012.02.063

[89] J. J. Gooding, V. R. Gonçales, Recent advances in the molecular level modification of electrodes for bioelectrochemistry, Curr. Opin. Electrochem., 5, 203-210 (2017). https://doi.org/10.1016/j.coelec.2017.09.018

[90] S. V. Sokolov, E. Katelhon, E. R. G. Compton, Understanding nano-impacts: reversible agglomeration and near-wall hindered diffusion, J. Electroanal. Chem., 779, 18-24 (2016). https://doi.org/10.1016/j.jelechem.2016.01.023

[91] X. Xiao, F.-R. F Fan, J. Zhou, A. J. Bard, Current transients in single nanoparticle collision events. J. Am. Chem. Soc., 130, 16669-16677 (2008). https://doi.org/10.1021/ja8051393
[92] M. A. Edwards, D. A. Robinson, H. Ren, C. G. Cheyne, C. S. Tan, H. S. White, Nanoscale electrochemical kinetics \& dynamics: the challenges and opportunities of single-entity measurements. Faraday Discuss., 210, 9-28 (2018). https://doi.org/10.1039/C8FD00134K

[93] H. Ma, H.-F. Fang, P.-J. Hu, W. Ma, Y.-T. Long, Exploring dynamic interactions of single nanoparticles at interfaces for surface confined electrochemical behavior and size measurement, Nat. Commun., 11, 2307 (2020). https://doi.org/10.1038/s41467-020-16149-0

[94] V. Mirceski, E. Laborda, D. Guziejewski, R. G. Compton, New approach to electrode kinetic measurements in square-wave voltammetry: amplitude-based quasireversible maximum, Anal. Chem. 85, 5586-5594 (2013). DOI:10.1021/ac40008573

[95] V. Mirceski, L. Stojanov, B. Ogorevc, Step potential as a diagnostic tool in square-wave voltammetry of quasireversible electrochemical processes, Electrochim. Acta 327, 134997 (2019). https://doi.org/10.1016/j.electacta.2019.134997

[96] V. Mirceski, D. Guziejewski, M. Bozem, I. Bogeski, Characterizing electrode reactions by multisampling the current in square-wave voltammetry, Electrochim. Acta 213, 520-528 (2016). https://doi.org/10.1016/j.electacta.2016.07.128

[97] D. Jadresko, D. Guziejewski, V. Mirceski, Electrochemical faradaic spectroscopy, Chem. ElectroChem 5, 187194 (2018). https://doi.org/10.1002/celc.201700784

[98] V. Mirceski, L. Stojanov, R. Gulaboski, DoubleSampled differential square-wave voltammetry, J. Electroanal. Chem., 872, 114384, (2020). https://doi.org/10.1016/j.jelechem.2020.114384 